\title{
LEAF AND STRIPE RUST RESISTANCE AMONG ETHIOPIAN GROWN WHEAT VARIETIES AND LINES
}

\author{
Shimelis Hussein * and Z.A. Pretorius \\ University of the Free State, Department of Plant Sciences, PO Box, 339, Bloemfontein 9300, South Africa
}

\begin{abstract}
Ethiopian grown wheat varieties and lines were studied to identify germplasm sources possessing resistance to leaf rust caused by Puccinia triticina and stripe rust (P. striiformis). Sixty-four lines were included of which 38 were bread wheat (Triticum aestivum, $2 n=6 x=42$, AABBDD) and 26 durum wheat ( $T$. turgidum, $2 \mathrm{n}=6 \mathrm{x}=42$, AABBDD). Controlled glasshouse studies were conducted by inoculating seedling plants using pathotypes of five $P$. triticina (UVPrt2, UVPrt3, UVPrt5, UVPrt9 and UVPrt13) and two $P$. striiformis (6E16A and 6E22A). The result indicated that 20 varieties and lines harbor resistance to the leaf rust and 26 to the stripe rust pathotypes showing infection types $<2+$. Twelve bread wheat varieties and lines (Et-13 A2, HAR 1407 [Tusie], HAR 1775 [Tura], HAR 1920, HAR 2192, HAR 2534, HAR 2536, HAR 2561, HAR 2563 and three durum lines (DZ-114-08, AL-138, AL-69) had resistance reactions to both pathogen pathotypes. These varieties and lines, therefore, may be utilized in leaf and stripe rust resistance breeding programs.
\end{abstract}

Key words/phrases: Leaf rust, resistance, stripe rust, Triticum aestivum, Triticum turgidum

\section{INTRODUCTION}

The wheat stripe (yellow) rust caused by Puccinia striiformis West. f. sp. tritici and leaf rust (P. triticina Eriks.) are major constraints to increased yield globally (Knott, 1989; Das et al., 1992). Yield losses due to rusts are variable because of differences in weather conditions, cultivar susceptibility and availability of inoculum. However, grain losses have been significant and estimated $\mathbf{b}$ reach 30$70 \%$ or even greater on susceptible varieties (Knott, 1989; Murray et al., 1994). High moisture and warm weather favor leaf rust development while stripe rust is important under cool and moist environmental conditions (Knott, 1989). To reduce losses cultural control methods, application of chemicals and use of resistant cultivars are employed by wheat growers. The use of resistant cultivars is the best strategy (Raupp et al., 2001).

Until presently 51 leaf rust $(L r)$ and 30 stripe rust $(Y r)$ genes have been reported worldwide that confer seedling and/or adult plant resistance (McIntosh et al., 1998; 2003). Selection for new sources of rust resistance remains important as earlier developed lines with single race-specific genes have mostly become ineffective due to the development of new and virulent pathotypes. Subsequently wheat rust researchers are constantly selecting new lines possessing additional and/or new resistance genes to complement the yield potential of cultivars (Sayre et al., 1998).

Resistance can be sought in seedlings and/or adult plants. Seedling resistance genes are recognised in primary leaves and normally confer resistance at all stages of plant growth (Sawhney et al., 1992). However, adult-plant resistance (APR) genes are not effective in seedlings and are the common sources of durable resistance. A combination of both seedling and adult-plant resistance is reported to occur in the presence of certain genes such as Lr34 (Dyck and Samborski, 1982) and Lr37 (Bariana and McIntosh, 1993). The genes for resistance can be demonstrated based upon the concepts of the gene-for-gene (Flor, 1942) and interorganismal genetics of host-pathogen association (Loegering, 1978; 1985).

Ethiopia and South Africa are situated in the same epidemiological zone of wheat rusts. It is

\footnotetext{
* Current address: University of Limpopo, School of Agricultural and Environmental Sciences, Private Bag X1106, Sovenga 0727, South Africa. E-mail: Shimelis@Ul.ac.za
} 
reported that within the same zone there is relatively free movement of the rust spores and the virulence of a rust population will tend to be similar. However, virulence shifts may occur from area to area within a zone if the predominant cultivars in different areas carry different genes for resistance (Knott, 1989). In Ethiopia the wheat rusts obstruct stable wheat production and productivity (Dagnachew Yirgou, 1967; Eshetu Bekele, 1985; Ayele Badebo et al., 1990). Yield losses due to wheat rusts may vary according to climatic conditions and cropping systems. However, it is not well quantified in economic terms. Farmers in Ethiopia still require improved rust resistant wheat varieties and lines to reduce yield losses. It is important to identify sources of resistance and exploit them in a resistance breeding programs. Selection for resistance among Ethiopian grown varieties and lines would be feasible as the country is believed to be the centre of diversity of durum wheat (Triticum turgidum L., AABB, $2 \mathrm{n}=4 \mathrm{x}=28$ ) (Vavilov, 1951; Harlan, 1969; 1992; Zohary, 1970). The present study has aimed at identifying germplasm sources possessing resistance to leaf rust and stripe rust among Ethiopian grown bread wheat ( $T$. aestivum L., AABBDD, $2 n=6 x=42$ ) and durum wheat. The information may help wheat rust researchers to introgress resistance genes to susceptible wheat cultivars and for subsequent gene deployment.

\section{MATERIALS AND METHODS}

\section{Plant materials}

A total of 64 bread wheat and durum wheat varieties and lines were included in the experiments. The list and detailed description of lines is presented in Table 1. Supplemental lines were included for comparative assessment. Ethiopian grown bread wheat and durum wheat seeds were kindly made available by Dr. Tadesse Dessalegn, from Adet Agricultural Research Centre of the Amhara Regional State, Ethiopia.

Table 1. Ethiopian-grown bread and durum wheat varieties and lines used in the study.

\begin{tabular}{|c|c|c|c|}
\hline No. & Variety/line & $\begin{array}{l}\text { Year released/ } \\
\text { Registered }\end{array}$ & Cross/selection \\
\hline \multicolumn{4}{|c|}{ Bread wheat $(2 n=6 x=42$, AABBDD $)$} \\
\hline 1. & Et-13 A2 & 1981 & UQ105 Sel. x ENKOY \\
\hline 2. & HAR 1709 (MITIKE) & 1993 & BOW28/RBC \\
\hline 3. & K 6290-Bulk & 1977 & (AF.MAYO x GEM) x Romany \\
\hline 4. & K 6295-4A & 1980 & Romany x GB -Gamenya \\
\hline 5. & Enkoy & 1974 & [HEBRAND sel./(WIS 245/ SUP51)]//[FR-FN/Y)².A) \\
\hline 6. & Romany B.C. & 1974 & $\mathrm{NA}^{(\mathrm{a})}$ \\
\hline 7. & Kanga & 1993 & MENCO/ (WIS245 x SUP51)/(FR-FN/Y)².A \\
\hline 8. & Mamba & 1973 & (AF.MY48/WIS245 x UP51)x(FR-FN/Y)2.A \\
\hline 9. & Dereselign & 1974 & $\mathrm{CI} 8154 / 2^{*} \mathrm{FR}$ \\
\hline 10. & Israel & Pre-1949 & NA \\
\hline 11. & Bonde & Pre-1949 & NA \\
\hline 12. & Salmayo & 1966 & NA \\
\hline 13. & Lakech & 1970 & PJ62/GB55 (118156) \\
\hline 14. & Pavon 76 & 1982 & $\mathrm{VCM} / / \mathrm{CNO} / 7 \mathrm{C} / 3 / \mathrm{KAL} / \mathrm{BB}(\mathrm{PAVON})$ \\
\hline 15. & Dashen & 1984 & KVZ/BUHO//KAL/BB (VEERY 5) \\
\hline 16. & Batu & 1984 & GLL/CUC//KVZ/SX (SUNBIRD) \\
\hline 17. & Gara & 1984 & $\mathrm{AU} / / \mathrm{KAL} / \mathrm{BB} / 3 / \mathrm{WOP}$ (BOBWHITE) \\
\hline 18. & HAR 407 & 1987 & KVZ/BUHO// KAL/BB (VEERY 15) \\
\hline 19. & HAR 416 & 1987 & $\mathrm{AU} / / \mathrm{KAL} / \mathrm{BB} / 3 /$ WOP (BOBWHITE 28$)$ \\
\hline 20. & HAR1685 (KUBSA) & 1994 & ND/VG9144//KAL/BB/3/YACO /4/VEERY \#5 (ATTILA) \\
\hline 21. & HAR710 (WABE) & 1994 & MRL/BUC \\
\hline 22. & HAR 604 (GALAMA) & 1995 & $4777 * 2 / / \mathrm{FLN} / \mathrm{GB} / 3 / \mathrm{PVN}$ \\
\hline 23. & HAR 1522 (ABOLA) & 1997 & BOW/BUC \\
\hline 24. & HAR 1407 (TUSIE) & 1997 & COOK/VEE//DOVE/SERI \\
\hline 25. & HAR 1595 (MAGAL) & 1997 & F3.71/TRM//BUC/3/LIRA \\
\hline 26. & HAR1706 & Advanced line & Bow 'S' \\
\hline 27. & HAR 1775 (TURA) & 1999 & AROYR Sel.60/1989 \\
\hline
\end{tabular}


Table 1. (Contd).

\begin{tabular}{|c|c|c|c|}
\hline No. & Variety/line & $\begin{array}{l}\text { Year released/ } \\
\text { registered }\end{array}$ & Cross/selection \\
\hline 28. & HAR1863 & Advanced line & BOW/URE \\
\hline 29. & HAR 1868 (SHINA) & 1999 & GOV9/AZ//MUS/3/R37/GHL21//KAL/BB/4/ANI \\
\hline 30. & HAR1901 & Advanced line & BUC /FLK / /MYNA/VUL \\
\hline 31. & HAR 1920 & 2000 & $\mathrm{MON} / \mathrm{VEE} / / \mathrm{SARA}$ \\
\hline 32. & HAR 2192 & 2002 & CM75113-B-5M-1Y-O5M-3Y-2B-OY (MILAN) \\
\hline 33. & HAR 2501 & 2000 & CHIL/PRL \\
\hline 34. & HAR 2508 & 2003 & $\mathrm{BJY} / \mathrm{COC} / / \mathrm{PRL} / \mathrm{BOW}$ \\
\hline 35. & HAR 2534 & 2003 & ND/VG9144//KAL/BB/3YACO/4/CHIL \\
\hline 36. & HAR 2536 & 2000 & PRL/VEE6/MYNA/VUL (PRINIA) \\
\hline 37. & HAR 2561 & Candidate & CM90722-22Y-OM-OY-3M-OY-4M-1M-OY (PRINIA) \\
\hline 38. & HAR 2563 & Candidate & CHUM18//JUP/BJY \\
\hline \multicolumn{4}{|c|}{ Durum wheat $(2 n=4 x=28$, AABB $)$} \\
\hline 39. & E-26 & NA & Landrace \\
\hline 40. & DZ-114-08 & 1966 & Landrace \\
\hline 41. & AL-138 & NA & Landrace \\
\hline 42. & AL-69 & NA & Landrace \\
\hline 43. & CADU \#17 & NA & Landrace \\
\hline 44. & BAHIRSEDED & NA & Landrace \\
\hline 45. & BOOHAI & 1982 & $\mathrm{COO} / \mathrm{CII}$ \\
\hline 46. & BOOHAI “S” & 1982 & CD 3862-1BS-1BS-1GDZ-1GDZ \\
\hline 47. & FOKA & 1983 & Cocorit $71 /$ Candeal II \\
\hline 48. & KILINTO & 1994 & ILLUMILO/INRAT69// BOOHAI/3/HorA/4/CIT 71/JORO \\
\hline 49. & Ld-357 & 1979 & Ld-357/CI8155 \\
\hline 50. & QUAMY & 1997 & $\mathrm{FG} / \mathrm{CR} / \mathrm{FG} / \mathrm{DOM} / 6 / \mathrm{HUI}$ \\
\hline 51. & TOB -66 & 1997 & REICHNBACHII/LD357//DUCK/YEL \\
\hline 52. & FETAN (TOP-2) & NA & NA \\
\hline \multirow[t]{2}{*}{53.} & DZ-393-4 (BICHENA) & 1995 & Illumilo/Cocori 71 \\
\hline & & & Dz04-1169/Dz04-129/Yemen Cit /PLCS/3/Tugaroy \\
\hline 54. & DZ-2023 & NA & B.B/4//5/Chen /PCHI//HUI/ TUB :3 \\
\hline 55. & DZ-1691 & NA & Boohai//Cit 71/Candeal II \\
\hline 56. & DZ-2085 (ASSASA) & 1997 & $\mathrm{CHO} / \mathrm{TARU} / / \mathrm{YAU} / 3 / \mathrm{Fg} / 4 / \mathrm{Fg} / \mathrm{kr} / 5 / \mathrm{Fg} / \mathrm{Dom} / 6 / \mathrm{HUI}$ \\
\hline 57. & DZ-1050 & 2000 & Boohai/ULNV \\
\hline 58. & DZ-1052 & NA & Boohai/4/Mexi //Chap/21563/3/Fg \\
\hline 59. & Gerardo & 1976 & VZ466/61-B0xLDsXGII \\
\hline 60. & Cocorit 71 & 1976 & $\mathrm{RAE} / 4 / \mathrm{TC} 60 / / \mathrm{TW} 63 / 3 / 3 / \mathrm{AA}$ \\
\hline 61. & DZ-575 & NA & Boohai/GDO Dz 466/61-130K Gll \\
\hline & & & Hora/Cit //JOO/GS/3/Some/4/Hora/Raspinegro//CM/ \\
\hline 62. & DZ-1640 (ROBE) & 1999 & 9908/3/Rahum \\
\hline 63. & DZ-966 & NA & $\mathrm{NA}$ \\
\hline 64. & DZ-1928-2 & NA & NA \\
\hline
\end{tabular}

NA=not available

\section{Growing conditions}

Resistance was studied through two independent tests by growing seedling plants in controlled rust free glasshouse cubicles at the University of the Free State, South Africa. Studies were conducted from September through December 2002 and April to August 2003. From each variety and line 10-15 seeds were sown in a $10 \mathrm{~cm}$ diameter plastic pots filled with steamsterilized soil. For leaf rust studies, the glasshouse day and night temperature was maintained at $20 \pm$ $5^{\circ} \mathrm{C}$ and $14 \pm 5^{\circ} \mathrm{C}$, respectively with a day light regime of $14 \mathrm{~h}$. The stripe rust studies were carried out by maintaining the glasshouse temperature at
$17 \pm 2^{\circ} \mathrm{C}$ with $16 \mathrm{~h}$ light and $8 \mathrm{~h}$ night regimes. The daylight was supplemented with $120 \mu_{\mathrm{molm}}^{-2} \mathrm{~s}^{-1}$ photosynthetically active radiation that was emitted from cool white fluorescent tubes arranged directly above plants. Seedling of 2 to $3 \mathrm{~cm}$ long were fertilized with a solution that contained $12.5 \% \mathrm{~N}, \quad 8.3 \% \mathrm{P}, \quad 4.2 \% \mathrm{~K}$ and $0.5 \% \mathrm{Zn}$ (Omnia Fertilizer Limited) at a rate of $10 \mathrm{~g} / 1$ and a solution of $50 \mathrm{ml}$ was applied per pot.

\section{Rust pathotypes, inoculum preparation and in- cubation}

Single pathotype of UVPrt2, UVPrt3, UVPrt5, UVPrt9 and UVPrt13 of P. triticina and 6E16A and 
6E22A of $P$. striiformis were used for inoculating seedling plants. The Department of Plant Sciences, the University of the Free State (South Africa) supplied the pathotypes. Based on the infection types on South African differential sets, the avirulence/virulence pattern of the pathotypes with respect to array of named resistance genes is presented in Table 2.

Fresh and sufficient inoculum was prepared using susceptible selective hosts (Table 2). At emergence seedlings of the selective hosts were treated with a solution of maleic hydrazide (MH) to retard plant development and encourage sporulation. A MH solution was prepared at a rate of $0.3 \mathrm{~g} / 1$ and $50 \mathrm{ml} /$ pot basally applied. Two days after applying $\mathrm{MH}$, seedlings were fertilized with a solution as described above. Week old seedlings were infected by spraying with urediniospores of both pathotypes. Fresh inoculum of stripe rust was used from growth chambers for inoculating the selective hosts. While urediniospores of leaf rust pathotypes kept under ultra low temperature (-156 ${ }^{\circ} \mathrm{C}$ ) in gelatin capsules were used after heat shock in warm water at $47^{\circ} \mathrm{C}$ for $6 \mathrm{~min}$. For inoculations urediospores were suspended in light mineral oil (Soltrol 70). The upper surfaces of primary leaves were uniformly inoculated with a pressurized sprayer by putting pots in an inoculation booth that was automatically rotating to allow uniform spraying. The booth was thoroughly cleaned after spraying and different pathotypes were handled separately to prevent contamination. Inoculated seedlings were allowed to dry for about $2 \mathrm{~h}$ before they were incubated. Leaf rust inoculated sets were incubated for $16 \mathrm{~h}$ at 20 to $24^{\circ} \mathrm{C}$ by placing in a moist chamber $(96 \% \mathrm{RH})$ while the stripe rust set was incubated for $48 \mathrm{~h}$ at $6{ }^{\circ} \mathrm{C}$. Seedlings were taken from the moist chambers and allowed to dry slowly for another $2 \mathrm{~h}$ and moved to glasshouse cubicle until sufficient spores were harvested for inoculating test plants.

Week old seedlings of test lines and varieties were infected by spraying with a single pathotype of leaf rust and stripe rust urediospores. For inoculation, fresh spores were harvested from susceptible hosts and a solution was prepared at standard spore concentration of $40 \times 10^{4}$ urediospores $/ \mathrm{ml}$ oil. The concentration was established by mixing about $1.5 \mathrm{mg}$ of urediospores per $\mathrm{ml}$ of the mineral oil followed by counting the number of spores under a counting chamber and light microscope. Before each inoculation suspensions were adjusted to the appropriate density. Growing conditions as well as pre- and post-inoculation procedures were followed as described above.

Table 2. Avirulence/virulence combinations of South African pathotypes of Puccinia triticina (UVPrt2, UVPrt3 UVPrt5 UVPrt9 and UVPrt13) and Puccinia striiformis (6E16A and 6E22A) and susceptible hosts used for increasing the pathotypes.

\begin{tabular}{|c|c|c|}
\hline Pathotype & Avirulence/Virulence genes & Susceptible host \\
\hline UVPrt2 & $\begin{array}{l}\text { Lr1, Lr2a, Lr2b, Lr3ka, Lr11, Lr15, Lr17, Lr20, Lr24, Lr26, } \\
\text { Lr30/Lr2c, Lr3a, Lr3bg, Lr10, Lr14a, Lr16 }\end{array}$ & Zaragoza \\
\hline UVPrt3 & $\begin{array}{l}\text { Lr3a, Lr3bg, Lr3ka, Lr10, Lr11, Lr14a, Lr16, Lr17, Lr20, Lr26, } \\
\text { Lr30/Lr1, Lr2a, Lr2b, Lr2c, Lr15, Lr24 }\end{array}$ & Agent \\
\hline UVPrt5 & $\begin{array}{l}\text { Lr1, Lr2a, Lr3bg, Lr10, Lr11, Lr14a, Lr15, Lr17, Lr24, } \\
\text { Lr26/Lr2b, Lr2c, Lr3a, Lr3ka, Lr16, Lr20, Lr30 }\end{array}$ & Thew \\
\hline UVPrt9 & $\begin{array}{l}\text { Lr2a, Lr2b, Lr3bg, Lr15, Lr16, Lr17, Lr26, Lr30/Lr1, Lr2a, Lr2b, } \\
\text { Lr2c, Lr10, Lr14a, Lr15, Lr17, Lr24 }\end{array}$ & Karee \\
\hline UVPrt13 & $\begin{array}{l}\text { Lr3a, Lr3bg, Lr3ka, Lr11, Lr16, Lr20, Lr30/Lr1, Lr2a, Lr2b, } \\
\text { Lr2c, Lr10, Lr14a, Lr15, Lr17, Lr24, Lr26 }\end{array}$ & Gamtoos \\
\hline 6E16A & 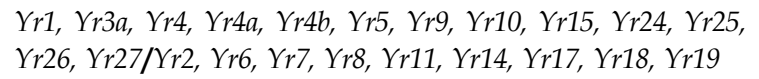 & Morocco \\
\hline $6 \mathrm{E} 22 \mathrm{~A}$ & 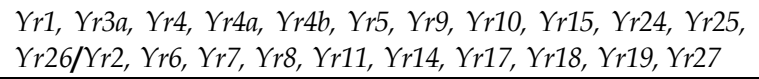 & Morocco \\
\hline
\end{tabular}




\section{Infection type assessment}

Infection types (ITs) were scored from primary seedling leaves of 14 , and 14 to 16 days after inoculation, respectively of leaf rust and stripe rust inoculated varieties and lines. The Stakman et al. (1962) scale as modified by Roelfs (1988) was used as a guide and the ITs were decided on 0 to 4 scale (Table 3). IT readings of 3 (medium-size uredia with/without chlorosis) and 4 (large uredia without chlorosis or necrosis) were regarded to show a compatible reaction. Other readings, i.e., 0 (immune), ; (flake), 1 (small uredia with necrosis), 2 (small to medium uredia with chlorosis or necrosis) were incompatible. Pustules that were accompanied by chlorosis or necrosis were indicated by " $\mathrm{C}$ " and "N"; respectively (Table 3). The variations above the established pustule sizes were indicated by a plus or minus sign (McIntosh et al., 1995).

Table 3. Seedling infection typesa of 38 bread wheat and 26 durum wheat grown in Ethiopia when tested to pathotypes of Puccinia triticina and Puccinia striiformis

\begin{tabular}{|c|c|c|c|c|c|c|c|c|}
\hline \multirow{3}{*}{ No. } & \multirow{3}{*}{ Line } & \multicolumn{7}{|c|}{ Pathogen and pathotype } \\
\hline & & \multicolumn{5}{|c|}{ P. triticina } & \multicolumn{2}{|c|}{ P. striiformis } \\
\hline & & UVPrt2 & UVPr3 & UVPrt5 & UVPrt9 & UVPrt13 & $6 \mathrm{E} 16 \mathrm{~A}$ & $6 \mathrm{E} 22 \mathrm{~A}$ \\
\hline \multicolumn{9}{|c|}{ Bread wheat } \\
\hline 1 & Et-13 A2 & $1 \mathrm{~N}$ & 1 & 1 & $1 \mathrm{~N}$ & $1 \mathrm{~N}$ & $1 \mathrm{~N}$ & $1 \mathrm{~N}$ \\
\hline 2 & HAR1709 & $2 \mathrm{C}$ & $3 C$ & $2 \mathrm{C}$ & 3 & 3 & 3 & $2 \mathrm{C}$ \\
\hline 3 & K 6290-BULK & $1 \mathrm{~N}$ & $3 C$ & $2 \mathrm{C}$ & $2 \mathrm{C}$ & $1 \mathrm{~N}$ & $3 C$ & 3 \\
\hline 4 & K 6295-4A & $2 \mathrm{C}$ & $1 \mathrm{~N}$ & $3 C$ & 3 & 3 & $2 \mathrm{C}$ & 2 \\
\hline 5 & ENKOY & 3 & $3 C$ & $3 C$ & 3 & 3 & ;C & $1 \mathrm{~N}$ \\
\hline 6 & KANGA & $2 \mathrm{C}$ & 3 & 3 & $1 C$ & $2 \mathrm{C}$ & $2 \mathrm{C}$ & $2 \mathrm{C}$ \\
\hline 7 & ROMANY B.C. & $1 C$ & $3 C$ & $2 \mathrm{C}$ & $3 C$ & 3 & $3 C$ & 4 \\
\hline 8 & MAMBA & $1 C$ & 4 & 3 & 3 & $3 C$ & $3 C$ & $3 C$ \\
\hline 9 & DERESELIGN & $2 \mathrm{C}$ & 3 & 4 & 3 & 3 & $1 \mathrm{C}$ & $3 C$ \\
\hline 10 & ISRAEL & 3 & 3 & 4 & 3 & 3 & $2 \mathrm{C}$ & 4 \\
\hline 11 & BONDE & $2 \mathrm{C}$ & 4 & $3 C$ & 4 & 4 & $1 \mathrm{~N}$ & $3 C$ \\
\hline 12 & SALAMAYO & $2+C$ & 4 & $2 \mathrm{C}$ & $2 C$ & 3 & 3 & 3 \\
\hline 13 & LAKECH & $2 \mathrm{C}$ & 3 & $2 \mathrm{C}$ & 3 & 4 & 4 & 4 \\
\hline 14 & PAVON 76 & ; & $1 \mathrm{~N}$ & ; & 3 & 3 & 4 & 4 \\
\hline 15 & DASHEN & ; & $1 \mathrm{~N}$ & $3 C$ & $1 \mathrm{~N}$ & 3 & ;N & ;N \\
\hline 16 & BATU & 0 & ; & ; & ; & 3 & ;N & ;N \\
\hline 17 & GARA & 0 & ;N & ;N & ;N & 3 & ;N & ;N \\
\hline 18 & HAR 407 & ; & $1 \mathrm{~N}$ & ;N & ;N & 3 & $1 \mathrm{~N}$ & ;N \\
\hline 19 & HAR 416 & ; & ;N & ; & $1 \mathrm{~N}$ & $3 C$ & ;N & ;N \\
\hline 20 & HAR 1685 (KUBSA) & $1 \mathrm{~N}$ & 4 & 4 & 4 & 4 & $3 C$ & $3 C$ \\
\hline 21 & HAR 710 ( WABE) & 0 & ; & ; & $1 \mathrm{~N}$ & ; & 3 & $1 \mathrm{~N}$ \\
\hline 22 & HAR604 (GALAMA) & 1 & ;N & $1 \mathrm{~N}$ & $1 \mathrm{~N}$ & ; & $1 \mathrm{~N}$ & 3 \\
\hline 23 & HAR 1522 (ABOLA) & 0 & $1 \mathrm{~N}$ & ; & $1 \mathrm{~N}$ & ; & $1 \mathrm{~N}$ & 3 \\
\hline 24 & HAR 1407 (TUSIE) & 0 & $1 \mathrm{~N}$ & ; & ; & ; & ; & ; \\
\hline 25 & HAR1595 & ; & $2 \mathrm{C}$ & 3 & 3 & 3 & $1 \mathrm{~N}$ & $1 \mathrm{~N}$ \\
\hline 26 & HAR 1706 & ; & $2 \mathrm{C}$ & $1 \mathrm{~N}$ & 3 & ; & $1 \mathrm{~N}$ & ;N \\
\hline 27 & HAR 1775 (TURA) & ; & ;N & ; & $1 \mathrm{~N}$ & ; & $1 \mathrm{~N}$ & ;N \\
\hline 28 & HAR 1863 & 0 & 3 & ; & ; & 3 & 0 & ;N \\
\hline 29 & HAR 1868 (SHINA) & $1 \mathrm{~N}$ & $3 C$ & 3 & 3 & 4 & $3 C$ & $3 C$ \\
\hline 30 & HAR1901 & 1 & $3 C$ & $2 \mathrm{C}$ & 4 & $3 \mathrm{C}$ & ;N & $3 C$ \\
\hline
\end{tabular}

a Results confirmed from two separate tests. 
Table 3. (Contd).

\begin{tabular}{|c|c|c|c|c|c|c|c|c|}
\hline \multirow{3}{*}{ No. } & \multirow{3}{*}{ Entry } & \multicolumn{7}{|c|}{ Pathogen and pathotype } \\
\hline & & \multicolumn{5}{|c|}{ P. triticina } & \multicolumn{2}{|c|}{ P. striiformis } \\
\hline & & UVPrt2 & UVPr3 & UVPrt5 & UVPrt9 & UVPrt13 & $6 \mathrm{E} 16 \mathrm{~A}$ & $6 \mathrm{E} 22 \mathrm{~A}$ \\
\hline$\overline{31}$ & HAR1920 & 0 & ; & ; & ; & ; & 0 & ; \\
\hline 32 & HAR 2192 & 0 & $; \mathrm{N}$ & ; & $1 \mathrm{~N}$ & $1 \mathrm{~N}$ & ;N & ; \\
\hline 33 & HAR 2501 & $1 \mathrm{~N}$ & $3 C$ & 4 & 3 & 3 & 4 & 4 \\
\hline 34 & HAR 2508 & 0 & $1 \mathrm{~N}$ & ; & ; & 3 & ; & ; \\
\hline 35 & HAR 2534 & 0 & ; & ; & ; & ; & ;N & ; \\
\hline 36 & HAR 2536 & 0 & ; & ; & ; & ; & ;N & ;N \\
\hline 37 & HAR 2561 & ; & ; & ;N & ; & ; & ; & ;N \\
\hline 38 & HAR 2563 & 0 & $1 \mathrm{~N}$ & ; & ; & ; & ; & ;N \\
\hline \multicolumn{9}{|c|}{ Durum wheat } \\
\hline 39 & E-26 & ; & $3 C$ & $1 \mathrm{~N}$ & 3 & 3 & $3 C$ & 4 \\
\hline 40 & DZ-114-08 & ; & $1 \mathrm{~N}$ & $1 \mathrm{~N}$ & $1 \mathrm{~N}$ & ; & $1 \mathrm{~N}$ & $2 \mathrm{C}$ \\
\hline 41 & AL-138 & 0 & $1 \mathrm{~N}$ & 0 & ; & ; & ; & ; \\
\hline 42 & AL-69 & ; & $1 \mathrm{~N}$ & ;N & ; & ; & ;N & ; \\
\hline 43 & CADU\#17 & 4 & 4 & 4 & 4 & 4 & 4 & 4 \\
\hline 44 & BAHIRSEDED & 3 & 4 & 3 & 4 & 3 & $3 C$ & 4 \\
\hline 45 & BOOHAI & 3 & 3 & 3 & 4 & ;N & $3 C$ & $3 C$ \\
\hline 46 & BOOHAI “S” & ;N & ;N & 3 & ;N & ; & 3 & ; \\
\hline 47 & FOKA & ; & ; & ; & ; & ; & $3 C$ & ; \\
\hline 48 & Kilinto & ; & 3 & ; & ; & ; & $3 C$ & ; \\
\hline 49 & LD-357 & ;N & $2 \mathrm{C}$ & ;N & ; & ;N & $3 C$ & ; \\
\hline 50 & QUAMI & ;N & ;N & ;N & ; & ;N & $3 C$ & ; \\
\hline 51 & TOB-66 & ; & ; & $1 \mathrm{~N}$ & ; & 3 & $3 C$ & ; \\
\hline 52 & FETAN(TOP-2) & $1 \mathrm{~N}$ & 3 & 4 & 3 & ; & $2 \mathrm{C}$ & $2 \mathrm{C}$ \\
\hline 53 & DZ-393-4 & $2 \mathrm{C}$ & 4 & 4 & $2 \mathrm{C}$ & 3 & $3 C$ & ; \\
\hline 54 & DZ-2023 & ;N & 0 & ;N & ;N & ;N & $3 C$ & ; \\
\hline 55 & DZ-1691 & ; & ;N & ;N & ;N & ;N & $3 C$ & ; \\
\hline 56 & DZ-2085 (ASASSA) & 3 & 3 & 4 & 3 & 3 & 4 & 4 \\
\hline 57 & DZ-1050 & $1 \mathrm{~N}$ & $2 \mathrm{C}$ & 3 & $2 \mathrm{C}$ & ;N & $3 C$ & $3 C$ \\
\hline 58 & DZ-1052 & $1 \mathrm{~N}$ & $3 C$ & 4 & ;N & $1 \mathrm{~N}$ & $3 C$ & 4 \\
\hline 59 & GERARDO & $1 \mathrm{~N}$ & $3 C$ & 3 & $2 \mathrm{C}$ & $2 \mathrm{C}$ & $3 C$ & $3 C$ \\
\hline 60 & COCORIT 71 & ; & 3 & $2 \mathrm{C}$ & $1 \mathrm{~N}$ & ;N & ; & $3 C$ \\
\hline 61 & DZ-575 & $1 \mathrm{~N}$ & $1 \mathrm{~N}$ & $3 C$ & $1 \mathrm{~N}$ & ;N & $3 C$ & $3 C$ \\
\hline 62 & DZ-1640 & 1 & $2 \mathrm{C}$ & $3 C$ & $2 \mathrm{C}$ & 3 & ; & $3 C$ \\
\hline 63 & DZ-966 & $1 \mathrm{~N}$ & 3 & 3 & $1 \mathrm{~N}$ & 3 & $2 \mathrm{C}$ & $2 \mathrm{C}$ \\
\hline 64 & DZ-1928-2 & $2 \mathrm{C}$ & $3 C$ & 4 & 3 & 3 & $3 C$ & $3 C$ \\
\hline \multicolumn{9}{|c|}{ Supplemental lines } \\
\hline 65 & RL 6003 & ; & 4 & $1 \mathrm{~N}$ & 3 & 3 & & \\
\hline 66 & RL 6002 & 3 & $1 \mathrm{~N}$ & 3 & 3 & $1 \mathrm{~N}$ & & \\
\hline 67 & Thew & $1 \mathrm{~N}$ & 2 & 4 & 4 & $1 \mathrm{~N}$ & & \\
\hline 68 & Gamtoos & ; & ;N & ; & $1 \mathrm{~N}$ & 3 & & \\
\hline 69 & Morocco & $2^{+} \mathrm{C}$ & 4 & 4 & 3 & 3 & 4 & 4 \\
\hline 70 & Reichersberg 42 & & & & & & ;N & $3 C$ \\
\hline 71 & Heines Peko & & & & & & ; & 3 \\
\hline 72 & Chinese 166 & & & & & & 0 & ;N \\
\hline 73 & Heines Kolben & & & & & & $3 C$ & 3 \\
\hline
\end{tabular}




\section{RESULTS}

\section{Selection for leaf rust resistance}

Infection types of both bread wheat and durum wheat varieties and lines against five $P$. triticina are summarized in Table 3 . The result indicated that 20 lines had resistance reactions to the pathotypes (ITs $<2^{+}$). The varieties and lines included Et-13, HAR 710 (Wabe), HAR 604 (Galama), HAR 1522 (Abola), HAR 1407 (Tusie), HAR 1775 (Tura), HAR 1920, HAR 2192, HAR 2534, HAR 2536, HAR 2561, HAR 2563, DZ114-08, AL-138, AL-69, Foka, LD-357, Quami, DZ2023, and DZ-1691. The first 12 lines are bread wheat and the remaining durum wheat. Bread wheat varieties and lines including Enkoy and Israel and durum wheat Cadu\#17, Bahirseded, and DZ-2085 (Assasa) were susceptible to all the leaf rust pathotypes (ITs $\geq 2^{+}$) similar to the susceptible standard 'Morocco'. The remaining 39 varieties and lines expressed heterogeneous reaction types to one or four of the pathotypes. UVPrt13 was relatively the most aggressive pathotype to the tested materials. Fifty percent of tested lines showed susceptible reactions to the pathotype. This pathotype was remarkably more aggressive to the bread wheat varieties and lines than durum wheat. Pathotypes UVPrt3 and UVPrt5 were the most aggressive to durum lines to which $50 \%$ were susceptible. Leaf rust pathotype UVPrt2 was the least aggressive. Only about $11 \%$ of tested lines (three bread wheat and four durum wheat lines) displayed susceptible reactions to pathotype UVPrt2.

\section{Selection for stripe rust resistance}

The seedling reactions of 64 wheat varieties and lines tested against two pathotypes of stripe rust are presented in Table 3. Twenty-one bread wheat lines [Et-13, K 6295-4A, Enkoy, Kanga, Dashen, Batu, Gara, HAR 407, HAR 416, HAR 1407 (Tusie), HAR 1595 (MAGAL), HAR 1706, HAR 1775 (Tura), HAR 1863, HAR 1920, HAR 2192, HAR 2508, HAR 2534, HAR 2536, HAR 2561, HAR 2563] and five durum lines [DZ-114-08， AL-138， AL-69， Fetan, D-Z695] expressed resistant reactions. Eight bread wheat lines (Romany B.C., Mamba, Salamayo, Laketch, Pavon 76, HAR 1685 (Kubsa), HAR 1868 (Shina), and
HAR 2501) and 10 durum wheat (E-26, Cadu\#17, Bahirseded, Boohai, DZ-2085 (Assasa), DZ-1050, DZ10-52, Gerardo, DZ-575, DZ-1928-2) were uniformly susceptible to the two pathotypes. Both stripe rust pathotypes were virulent to $50 \%$ of tested varieties and lines (Table 3). Pathotype 6E16A was more aggressive to durum wheat than bread wheat. Cadu\#17, Bahirseded and DZ-2085 (Assasa) had susceptible reactions similar to 'Morocco' (Table 3).

Twelve of the tested varieties and lines had resistance against five leaf rust and two stripe rust pathotypes of South African origin. These lines include Et-13, HAR 1407 (Tusie), HAR 1775 (Tura), HAR 1920, HAR 2192, HAR 2534, HAR 2536, HAR 2561, HAR 2563, DZ-114-08, AL-138, and AL-69. The first nine are bread wheat and the last three durum wheat. The bread wheat varieties and lines identified with resistance are either released or candidates for large area productions. The resistant durum lines are landraces, which are largely grown in Ethiopia.

\section{DISCUSSION}

Sixty-four Ethiopian grown bread and durum wheat were tested under controlled glasshouse conditions to study leaf rust and stripe rust seedling resistance. Nine bread wheat varieties and lines \{Et-13 A2, HAR 1407 (Tusie), HAR 1775 (Tura), HAR 1920, HAR 2192, HAR 2534, HAR 2536, HAR 2561 and HAR 2563\} and three durum varieties and lines (DZ-114-08, AL-138 and AL-69) possess resistance to five leaf and two stripe rust pathotypes recurring in South Africa. Except line Et-13 A2 that was released in 1981 others including HAR 1407, HAR 1775, HAR 1920, and HAR 2536 were recent releases. Bread wheat varieties and lines HAR 2192, HAR 2534, HAR 2561, and HAR 2563 are advanced or recent releases and currently expressed adequate resistance. The tetraploid landraces DZ-114-08, AL138 and AL-69 displayed resistant reactions.

The result indicated that bread wheat variety $\mathrm{K}$ 6290-bulk possessed resistance to four leaf rust pathotypes except UVPrt3. This line was developed from crosses with variety Mayo. Mayo 52 and 54 
were reported to carry Lr10 by Anderson (1961). Further, HAR 2563 was considerably resistant to the studied pathotypes. Singh (1992) reported Jupateco, one of the progenitors of this line, as carrier of Lr17a and Lr27. Singh and Rajaram (1994) described Jupateco carrying Yr18, which might have conferred stripe rust resistance in HAR 2563. Et-13 A2 showed resistance against the two stripe rust pathotypes. The pedigree of line Et-13 A2 indicates that Enkoy is one of its progenitors. Ayele Badebo et al. (1990) identified Enkoy with Yr3. Presently Enkoy is found resistant towards both stripe rust pathotypes. The current study has also identified Dashen to be resistant to the two stripe rust pathotypes. This variety was the result of crosses to Veery\#5 reported to carry $Y_{r} 7$ and $Y_{r} 9$ by Dubin et al. (1989). Dashen also expressed resistance reactions to UVPrt2, UVPrt3 and UVPrt9 owing to the presence of Lr9 descended from variety Veery (Merker, 1982). Variety HAR 1407 (Tusie) has shown resistance reactions to both stripe rust pathotypes. One of the parents of HAR 1407 is Maris Dove that carries Yr6 (McIntosh et al., 1998).

There is no earlier report that described durum landraces DZ-114-08, AL-138 and AL-69 as a source of leaf rust or stripe rust resistance. Therefore, the lines could be considered as sources of resistance to increase the genetic diversity in breeding programs. Landraces of wheat are considered as a primary genepool (Friebe et al., 1996) to enhance genetic variation in bread wheat (Triticum aestivum L., AABBDD, $2 n=6 x=42$ ). Wheat landraces from Ethiopia have been reported as valuable genetic resources because of their rust resistance, long coleoptile, short culm, low tillering, early maturity and drought resistance (Perrino and Porceddu, 1990). There are also evidences that suggest the presence of considerable level of resistance among Ethiopian wheat germplasm that could be selected for strategic breeding for rust resistance (Tesfaye Tessema, 1987; Ayele Badebo et al., 1990).

The study concluded that a considerable level of seedling plant resistance is available from Ethiopian grown wheat varieties and lines when tested by known leaf rust and stripe rust pathotypes presently recurring in South Africa. Since the two countries fall in the same epidemiological zone of wheat rusts (Knott, 1989) the information could be useful to wheat rust researchers. It is worthwhile, however, to note a possible occurrence of virulence shifts from area to area within a zone. This could be attributed by differences in the predominant cultivars grown in these areas that may carry different genes for resistance. Consequently it is required to make detailed studies by including the prevailing rust pathotypes of Ethiopian origin and using diverse germplasm as well as standard differential lines. Further, it is imperative to examine adult-plant resistance as it is a common source of durable resistance.

\section{ACKNOWLEDGEMENTS}

The Department of Plant Pathology, University of the Free State (South Africa) is sincerely acknowledged for providing facilities, supplemental lines and rust pathotypes. Dr. Tadesse Dessalegn is thanked for supplying Ethiopian grown wheat varieties and lines.

\section{REFERENCES}

1. Anderson, R.G. (1961). The inheritance of leaf rust resistance in seven varieties of common wheat. Canadian Journal of Plant Science 41:342-359.

2. Ayele Badebo, Stubbs, R.W., van Ginkel, M. and Getinet Gebeyehu (1990). Identification of resistance genes to Puccinia striformis in seedlings of Ethiopian and CIMMYT common wheat varieties and lines. Netherlands Journal of Plant Pathology 96:199-210.

3. Bariana, H.S. and McIntosh, R.A. (1993). Cytogenetic studies in wheat XV. Chromosome location of rust resistance genes in VPM1. Genome 36:476482.

4. Dagnachew Yirgou (1967). Plant diseases of common economic importance in Ethiopia. Haile Sellasie I University, Debre Zeit, Ethiopia, pp. 10-11.

5. Das, M.K., Rajaram, S., Mundt, C.C. and Kronstad, W.E. (1992). Inheritance of slow-rusting resistance to leaf rust of wheat. Crop Science 32:14521456. 
6. Dubin, H.J., Johnson, R. and Stubbs, R.W. (1989). Po stulated genes to stripe rust in selected CIMMYT and related wheats. Plant Disease 73:472-475.

7. Dyck, P.L. and Samborski, D.J. (1982). The inheritance of resistance to Puccinia recondita in a group of common wheat cultivars. Canadian Journal of Genetics and Cytology 24:273-283.

8. Eshetu Bekele (1985). A review of research on diseases of barley, tef and wheat in Ethiopia. In: A Review of Grop Protection Research in Ethiopia, pp. 79 -107, (Tsedeke Abate, ed.) Institute of Agricultural Research, Ethiopia.

9. Flor, H.H. (1942). Inheritance of pathogenicity in Melampsora lini. Phytopathology 32:653-669.

10. Friebe, B., Jiang, J., Raupp, W.J., McIntosh, R.A. and Gill, B.S. (1996). Characterization of wheat-alien translocations conferring resistance to diseases and pests: current status. Euphytica 91:59-87.

11. Harlan, J.R. (1969). Ethiopia: a centre of diversity. Economic Botany 23:309-314.

12. Harlan, J.R. (1992). Crops and Man, 2nd ed. American Society of Agronomy Inc., Crop Science Society of America, Inc., Madison, USA.

13. Knott, D.R. (1989). The Wheat Rusts - Breeding for Resistance. Springer-Verlag, Germany.

14. Loegering, W.Q. (1978). Current concepts in interorganismal genetics. Annual Review of Phytopathology 16:275-296.

15. Loegering, W.Q. (1985). Genetics of the pathogenhost associations. In: The Cereal Rusts. Vol. I., pp. 165-190, (Bushnell, W.R. and Roelfs, A.P., eds). Academic Press, New York.

16. McIntosh, R.A., Friebe, B., Jiang, J., The, D. and Gill, B.S. (1995). Chromosomal location of a new gene for resistance to leaf rust in a Japanese wheat-rye translocation line. Euphytica 82:141147.

17. McIntosh, R.A., Hart, G.E., Devos, K.M. Gale, M.D. and Rogers, W.J. (1998). Catalogue of gene symbols for wheat, Vol. 5. In: Proceedings of the $g^{h}$ International Wheat Genetics Symposium, pp. 134139,. (Slinkard, A.E., ed.) University Extension Press, University of Saskatchewan, Saskatoon, Canada.

18. McIntosh, R.A., Yamazaki, Y., Devos, K.M., Dubcovsky, J., Rogers, J. and Apples, R. (2003). MacGene 2003, Catlaogue of Gene Symbols for Wheat, Compact Disc, 10th International Wheat Genetics Symposium, Rome, Italy.
19. Merker, A. (1982). "Veery" - a CIMMYT spring wheat with the 1B/1R chromosome translocation. Cereal Research Communications 10:105-106.

20. Murray, G.M., Ellison, P.J., Watson, A. and Cullis, B.R. (1994). The relationship between wheat yield and stripe rust as affected by length of epidemic and temperature at the grain development stage in some Australian wheats. Plant Pathology 43:215-222.

21. Perrino P, and Porceddu, E. (1990). Wheat genetic resources in Ethiopia and the Mediterranean region. In: Wheat genetic resources: meeting diverse needs, p.p. 161-178, (Srivastava, J.P. and Damania, A.B., eds). John Wiley and Sons, Chichester.

22. Raupp, W.J., Singh, S., Brown-Guedira, G.L., and Gill, B.S. (2001). Cytogenetic and molecular mapping of the leaf rust resistance gene Lr39 in wheat. Theoretical and Applied Cenetics 102:347352.

23. Roelfs, A.P. (1988). Genetic control of phenotypes in wheat stem rust. Annual Review of Phytopathology 26:351-367.

24. Sawhney, R.N., Sharma, J.B. and Sharma, D.N. (1992). Genetic diversity for adult plant resistance to leaf rust (Puccinia recondita) in near-isogenic lines and Indian wheats. Plant Breeding 109:248254.

25. Sayre, K.D., Singh, R.P., Huerta-Espino, J. and Rajaram, S. (1998). Genetic progress in reducing losses to leaf rust in CIMMYT-derived Mexican spring wheat cultivars. Crop Science 38:654-659.

26. Singh, R.P. (1992). Association between gene Lr34 for leaf rust resistance and leaf tip necrosis in wheat. Crop Science 32:874-878.

27. Singh, R.P. and Rajaram, S. (1994). Genetics of adult plant resistance to stripe rust in ten common wheats. Euphytica 72:1-7.

28. Stakman, E.G., Stewart, D.M. and Loegering, W.Q. (1962). Identification of physiological races of Puccinia graminis var. tritici. U.S. Department of Agriculture. Agricultural Research Service E 617.

29. Tesfaye Tessema (1987). Durum wheat breeding in Ethiopia. In: Fifth Regional Wheat Workshop for Eastern, Central, Southern Africa and the Indian Ocean, (van Ginkel, M. and Tanner, D.G. eds). CIMMYT, Mexico, DF. 
30. Vavilov, N.I. (1951). The Origin, Variation, Immunity and Breeding of Cultivated Pants. Selected writings translated from the Russian by K. Starr Chester, The Ronald Press Company, New York, pp. 346.
31. Zohary, D. (1970). Centers of diversity and centers of origin. In: Genetic resources in plants: their exploration and conservation, pp. 33-42, (Frankel, O.H., Bennett, M.D., eds). Blackwell, Oxford and Edinburgh. 